Piotr ZYZAK ${ }^{1}$, Piotr KOŁODZIEJCZYK ${ }^{2}$

Opiekun naukowy: Piotr ZYZAK ${ }^{1}$

DOI: https://doi.org/10.53052/9788366249837.39

\title{
ProjeKT ORAZ WYKONANIE ROBOTA WRAZ ZE STEROWANIEM BEZPRZEWODOWYM
}

\begin{abstract}
Streszczenie: Artykuł przedstawia wybrane aspekty procesu projektowania modelu robota przemysłowego, jego wykonanie i programowanie do wykonywania zadanych pozycji. Sterowanie modelu robota jest realizowane przy pomocy wykonanej aplikacji na smartfon z systemem Android, stosując połączenie Bluetooth lub Wi-Fi z różnymi modułami komunikacyjnymi programowalnymi w języku Arduino. Zaprezentowano również wybrane wyniki badań dotyczących wpływu odległości, oraz różnych przeszkód, na opóźnienie w transmisji danych.
\end{abstract}

Słowa kluczowe: model robota przemysłowego, komunikacja bezprzewodowa, transmisja danych

\section{DESIGN AND EXECUTION OF THE ROBOT WITH WIRELESS CONTROL}

Summary: The article presents selected aspects of the design process of an industrial robot model, its execution and programming to perform given positions. The robot model is controlled using an application for an Android smartphone, using a Bluetooth or Wi-Fi connection with various communication modules programmable in the Arduino language. Selected results of research on the effect of distance and various obstacles on the delay in data transmission are also presented.

Keywords: industrial robot model, wireless communication, data transmission

\section{Wprowadzenie}

W dzisiejszych czasach przemysł nieuchronnie dąży do robotyzacji wszelakich czynności, które niegdyś były wykonywane tylko przez człowieka. Roboty dzięki swojej precyzji, powtarzalności czy odporności na niebezpieczne warunki mogą

1 Akademia Techniczno-Humanistyczna w Bielsku-Białej, Wydział Budowy Maszyn i Informatyki,pzyzak@ath.bielsko.pl

2 Akademia Techniczno-Humanistyczna w Bielsku-Białej, Wydział Budowy Maszyn i Informatyki, Automatyka Przemysłowa, piotr.kolodziejczyk95@gmail.com 
odciążyć pracowników od prac, które mogłyby narazić na niebezpieczeństwo. W zależności od konstrukcji, znajdują zastosowanie w wielu różnorodnych branżach. Dowolność w programowaniu takich maszyn pozwala na wykorzystywanie ich zarówno przy liniach produkcyjnych czy przy kooperacji zczłowiekiem, jak i mobilnie lub na przykład sterując bezprzewodowo.

Zdalne kierowanie ruchami robotów znajduje zastosowanie m. in. w medycynie, gdzie chirurdzy za pomocą sieci internetowej mogą wykonywać operacje będąc np. na drugim końcu świata. Zdalne sterowanie urządzeniami jest częścią Przemysłu 4.0 i wprowadza wygodę w użytkowaniu, ze względu na brak konieczności stosowania połączeń elektrycznych, które są nie tylko ograniczeniem dla operatora, ale stwarzają ryzyko potknięcia się lub uszkodzenia przewodów panelu sterującego. Coraz więcej maszyn przemysłowych wyposażonych jest w moduły umożliwiające podłączenie ich do sieci, które dostarczają informacji o stanie technicznym i dają możliwość sterowania nimi. Obecnie temat transmisji danych jest cały czas rozwijany, wprowadzane są coraz to szybsze połączenia, a także zwiększane bezpieczeństwo sieci.

\section{2. Środowiska programistyczne wykorzystywane do obsługi sterowników oraz urządzeń mobilnych}

\section{1. Środowisko Arduino IDE}

Arduino IDE jest darmowym, łatwym w obsłudze zintegrowanym środowiskiem programistycznym, umożliwiającym pisanie kodu $\mathrm{w}$ języku $\mathrm{C} / \mathrm{C}++$, a także jego zamianę na język zrozumiały dla mikrokontrolera (kompilacja) oraz wgrywanie do niego. Szeroka baza posiadanych lub możliwych do pobrania płytek dostępnych na rynku, a także gotowych bibliotek ułatwia pisanie programów, dzięki czemu kod źródłowy jest czytelniejszy i łatwiejszy do analizy. Program posiada monitor portu szeregowego, który wyświetla informacje wymieniane $\mathrm{z}$ mikrokontrolerem po podłączeniu z komputerem [1].

MIT App Inventor to program online dostępny po wejściu przez przeglądarkę internetową, służący do projektowania aplikacji mobilnych na urządzenia z systemem Android. Składa się z trzech głównych segmentów. Pierwszy pozwala na edycje ekranów aplikacji poprzez graficzne rozmieszczanie elementów interfejsu, definiowanie mediów czy też łączności, które posiada obsługiwane urządzenie. Kolejnym komponentem jest Edytor Blokowy, w którym pisany jest program poprzez umieszczanie bloków z przypisanymi funkcjami. W edytorze tym znajdują się bloki wbudowane, jak i te przypisane do poszczególnych elementów dodanych do edytowanego ekranu. Do testowania aplikacji potrzebny jest emulator, czyli wirtualny telefon instalowany na komputerze albo urządzenie $\mathrm{z}$ systemem Android wyposażonym w aplikację MIT AI2 Companion podłączone do tej samej sieci Wi-Fi co komputer lub przewodem USB. Wprowadzane zmiany w przeglądarce są systematycznie przesyłane do aplikacji testowej. Gotowy projekt kompilowany jest w postaci pliku z rozszerzeniem .apk, który następnie może być instalowany na urządzeniu [2]. 


\subsection{Komunikacja bezprzewodowa Wi-Fi}

Wi-Fi jest to technologia umożliwiająca budowę bezprzewodowego podłączenia się do sieci komputerowej (np. WLAN). Wykorzystuje do tego standardy IEEE 802.11, które zapewniają transmisję w paśmie o częstotliwości $2,4 \mathrm{GHz}$ lub $5 \mathrm{GHz}$ o różnej przepustowości w zależności od rodzaju standardu. W idealnych warunkach prędkość transmisji danych szacuje się na $11 \mathrm{Mb} / \mathrm{s}$ dla standardu $802.11 \mathrm{~b}$ do $10 \mathrm{~Gb} / \mathrm{s}$ dla 802.11 ax. Wartości te ulegają zmianie wraz z odległością, przestrzenią, w której są obecne czy obiektami znajdującymi się pomiędzy urządzeniami komunikującymi się ze sobą. Zasięg punktu dostępu w tej technologii szacuję się na około $46 \mathrm{~m}$ w zamkniętych pomieszczeniach, a na zewnątrz do $92 \mathrm{~m}$ dla urządzeń pracujących w paśmie 2,4 GHz. Parametry te można poprawić stosując odpowiednie anteny, przedłużając dystans nawet do $8 \mathrm{~km}$. Dzięki sieciom bezprzewodowym Wi-Fi można uzyskać prosty i szybki dostęp bez konieczności stosowania kabli zarówno do sieci przewodowych LAN, jak i bezprzewodowej WLAN. Zapewniają użytkownikom mobilność, można je rozbudowywać, poszerzając zasięg. Wraz ze wzrostem liczby podłączonych do tej samej sieci urządzeń, prędkość przesyłania danych maleje, co prowadzi do wolniejszej komunikacji między urządzeniami $[3,4,6]$.

\subsection{Komunikacja bezprzewodowa Bluetooth}

Podobnie jak sieci Wi-Fi, Bluetooth jest bezprzewodowym rozwiązaniem przesyłania danych, który opisany jest standardem IEEE 802.15.1 i również pracuje w paśmie 2,4 GHz. Cechuje się niskim zużyciem energii, co wiąże się z krótkim zasięgiem. Jest substytutem dla połączeń przewodowych przy wymianie informacji między np. komputerem czy smartfonem, a różnymi urządzeniami peryferyjnymi takimi jak klawiatura, drukarka, samochodowy zestaw głośnomówiący. Zastosowaniu techniki FHSS (rozpraszanie widma sygnału z przeskokiem częstotliwości) rozwiązuje problemy z zabezpieczeniem połączenia przed przejęciem danych oraz rozwiązuje kwestie związane $\mathrm{z}$ interferencją, co czyni standard Bluetooth odpornym na zakłócenia. Zasięg połączenia Bluetooth szacuje się na około $10 \mathrm{~m}$ do $100 \mathrm{~m}$, a w otwartej przestrzeni nawet do $200 \mathrm{~m}$. Prędkość w zależności od generacji wynosi od $21 \mathrm{~kb} / \mathrm{s}$ dla Bluetooth 1.0 i nawet $50 \mathrm{Mb} / \mathrm{s}$ dla wersji 5.0 [5].

\section{Ogólny przegląd rozwiązań sterowania robotami}

Przy pracy z robotami, jedną z najważniejszych kwestii jest komunikacja z nimi, polegająca na programowaniu, zadawaniu ruchów czy odczytywaniu danych, które są przez nie dostarczane. Do tego celu wykorzystuje się np. komputery stacjonarne czy panele operatorskie, które można połączyć ze sterownikiem poprzez standard Ethernet czy transmisję szeregową (RS-232, RS485, USB). Oprogramowania inżynierskie $\mathrm{z}$ funkcją HMI lub system SCADA dają dostęp do urządzeń znajdujących się w obrębie sieci stosując protokoły takie jak SRTP, Modbus TCP, EGD, Modbus RTU, w zależności od standardu. Do sterowania robotami używa się także specjalnych paneli uczących (Teach Pendant) z systemem który umożliwia ich pełną obsługę. Do transmisji danych zamiast powszechnie stosowanych przewodów miedzianych można wykorzystać światłowody, które zapewniają kilkukrotnie razy 
szybszą transmisję, a także większą odległość maksymalną między węzłami sieci $[7,8]$.

Alternatywą do komunikacji przewodowej, jest coraz częściej wdrażana w przemyśle i nie tylko, transmisja zdalna, wykorzystująca fale optyczne lub radiowe, pracująca $\mathrm{z}$ różną częstotliwością $\mathrm{w}$ zależności od stosowanego standardu. Cały czas rozwijająca się technologia bezprzewodowa pozwala na uzyskiwanie coraz to większych prędkości, jakości, a także poziomu zabezpieczeń, co zwiększa elastyczność komunikacji z maszynami.

Do najpopularniejszych technologii bezprzewodowej wymiany informacji można zaliczyć:

- Wi-Fi - pracuje w paśmie częstotliwości 2,4 GHz oraz $5 \mathrm{GHz}$. W robotyce standard ten znalazł zastosowanie np. w autonomicznych robotach mobilnych, które stale komunikują się ze sobą w celu określenia swoich pozycji. Do ich zarządzania stosuje się np. tablety $\mathrm{z}$ aplikacją, które poprzez Wi-Fi dają dostęp m.in. do generowania i podglądu trajektorii ruchu. Bezprzewodowe panele operatorskie (WiTP) stanowią substytut dla tych przewodowych w obszarach, gdzie na przykład istnieje ryzyko uszkodzenia okablowania. Będąca na wyposażeniu niemal wszystkich smartfonów i tabletów, technologia ta daje łatwy i szybki dostęp prawie każdemu, bez konieczności inwestowania w dodatkowe kontrolery. Prędkości komunikacji sięgają obecnie nawet kilku $\mathrm{Gb} / \mathrm{s}$, a zasięg ograniczony jest do liczby routerów pracujących w danej sieci.

- Bluetooth - transmisja odbywa się w paśmie częstotliwości 2,4 GHz. Moduły z tą technologią są częstym wyborem wśród hobbystów do sterowania urządzeniami mobilnymi, ze względu na łatwość parowania oraz prostotę w programowaniu. Do kontrolowania wykorzystywane są np. kontrolery do konsol czy wirtualnej rzeczywistości, które wyposażone są nie tylko w przyciski fizyczne, ale też czujniki pozwalające na sterowanie gestami. Zaimplementowany w sprzętach domowych daje możliwość sterowania takimi urządzeniami jak mobilne kosiarki czy odkurzacze poprzez smartfon lub tablet $\mathrm{z}$ dedykowaną aplikacją. W przemyśle stosowane są do konserwacji i sterowania urządzeniami na krótkich dystansach.

- RF - do przesyłania sygnału wykorzystuje fale radiowe. Najpopularniejsze moduły radiowe wykorzystują pasma częstotliwości $433 \mathrm{MHz}, 868 \mathrm{MHz}$ oraz 2,4 GHz. Zastosowanie znalazły w automatyce domowej (do sterowania oświetleniem, roletami alarmem itp.), do sterowania modelami RC (drony, pojazdy, roboty mobilne), w przemyśle (urządzenia $\mathrm{z}$ napędem elektrycznym lub hydraulicznym, żurawie, suwnice). Wyróżniają się dobrym zasięgiem od kilkudziesięciu metrów do kilku kilometrów lecz kosztem prędkości transmisji, który plasuje się na poziomie dochodzącym do $2 \mathrm{Mb} / \mathrm{s}$. [6]

- IrDA - dane transmitowane są przy pomocy podczerwieni (długość fali 850 - $900 \mathrm{~nm}$ ). Prędkość komunikacji wynosi od 2,4 kb/s do $4 \mathrm{Mb} / \mathrm{s}$, natomiast zasięg jaki oferuje IrDA zwykle nie przekracza 3 metrów. Prawidłowe połączenie tą metodą wymaga, aby podczas transmisji pomiędzy urządzeniami nie znajdowały się żadne przeszkody, które mogłyby uniemożliwić ich wzajemną widoczność. Standard IrDA można wykorzystać na przykład do emulacji łącza szeregowego lub równoległego RS-232 lecz powszechnie stosuje się go m.in. w niektórych telefonach czy pilocie TV [9].

$\mathrm{Z}$ racji, że smartfony wyposażone są w moduł Wi-Fi oraz Bluetooth oraz dostępność darmowych programów do wykonywania aplikacji na system Android, zdecydowano 
się na wykonanie projektu w oparciu o moduły właśnie z tymi technologiami. Dzięki możliwości sterowania przez aplikację na smartfonie, zbędnym staje się wykonywanie osobnych kontrolerów do każdego ze standardu transmisji.

\section{Projekt robota sterowanego bezprzewodowo}

Zdecydowano się na opracowanie projektu modelu robota wybrano o strukturze antropomorficznej. Wzorowano się na istniejącym robocie paletyzującym IRB 460 firmy ABB przedstawionym na rysunku 1 [10]. Posiada on rozwiązanie konstrukcyjne eliminujące dźwiganie masy dwóch napędów. Wyposażenie konstrukcji mechanizmu kinematycznego w łączniki równoległe do członów tworzy system równoległoboków. Dzięki takiej koncepcji kiść robota jest cały czas w tej samej pozycji, co sprawdza się przy układaniu towarów. Podczas projektowania dokonano modyfikacji i uproszczeń konstrukcyjnych z uwagi na materiał z jakiego manipulator ma zostać wykonany, a także na mechanizmy napędzające człony.

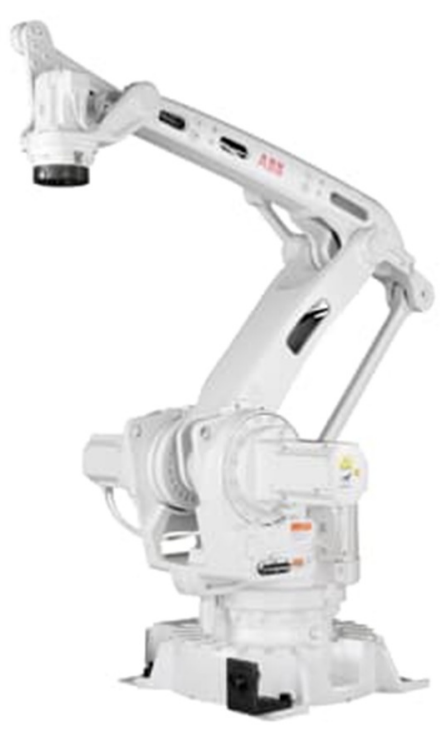

Rysunek 1. Robot paletyzujący IRB 460 firmy ABB [10]

Modelowanie robota wykonano przy pomocy oprogramowania Autodesk Inventor Professional 2020 . Projekt składa się z 20 poszczególnych części.

Do wykonania zaprojektowanych elementów przewidziano zastosowanie technologii druku 3D, z użyciem materiału PET-G, dzięki czemu proces modelowania jest o wiele szybszy, łatwiejszy, a także tańszy niż w przypadku wykorzystania materiałów metalowych, których koniecznym jest obróbka na obrabiarkach.

Rysunek 2 przedstawia projekt modelu robota $\mathrm{z}$ połączonych wszystkich zamodelowanych w programie Inventor elementów składowych. 


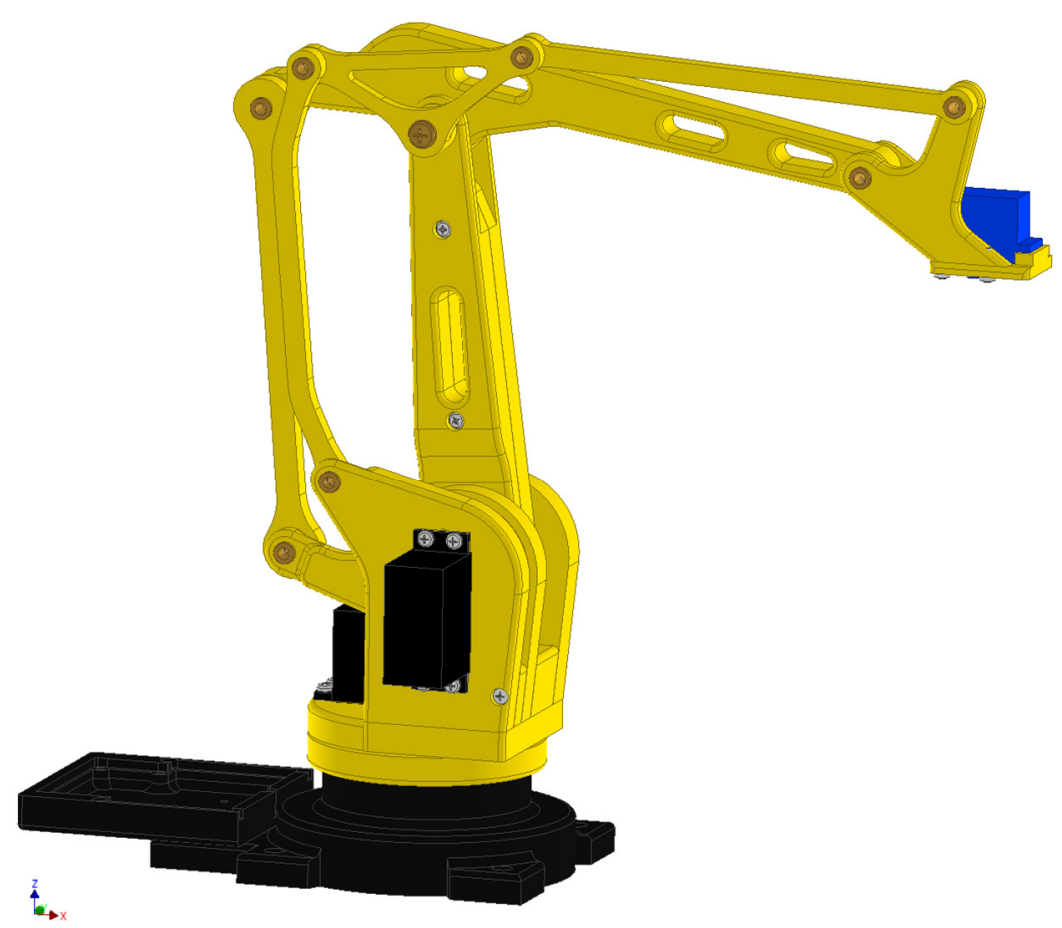

Rysunek 2. Widok opracowanego modelu robota [13]

\section{Wykonanie konstrukcji robota sterowanego bezprzewodowo}

Rozdział ten przedstawia wybrane istotne etapy wykonania modelu robota, począwszy od wytworzenia zaprojektowanych części techniką druku 3D, przez montaż elementów, aż po podłączenie elektroniki obsługującej robota. W pierwszej kolejności zapisano wszystkie modele elementów składowych konstrukcji w formacie pliku STL. Następnie przy pomocy programu komputerowego Ultimaker Cura v 4.8 wygenerowano plik G-code zawierający parametry druku oraz trajektorię poruszania się głowicy drukarki 3D. Najważniejsze parametry druku: wysokość warstwy: 0,2 mm, wypełnienie: $30 \%$, wzór wypełnienia: linie, temperatura druku: $240{ }^{\circ} \mathrm{C}$, temperatura stołu: $70{ }^{\circ} \mathrm{C}$, prędkość druku: $50 \mathrm{~mm} / \mathrm{s}$, prędkość przemieszczania: $100 \mathrm{~mm} / \mathrm{s}$, retrakcja: włączona.

Drukowanie zespołów konstrukcji mechanizmu kinematycznego zrealizowano za pomocą drukarki 3D Anycubic I3 Mega. Jest to drukarka drukująca w technologii druku FDM. Wymiary stołu wynoszą $210 \times 210 \mathrm{~mm}$,natomiast maksymalna wysokość druku wynosi 205 mm. Średnica zamocowanej dyszy ma wartość 0,4 mm.

Po wydrukowaniu elementów, przeprowadzono ręczną obróbkę elementów, polegającą na usunięciu podpór, powstałych ,nitek” oraz drobnych wady druku. Na rysunku 3 przedstawiono wszystkie wydrukowane części konstrukcji mechanizmu robota. 


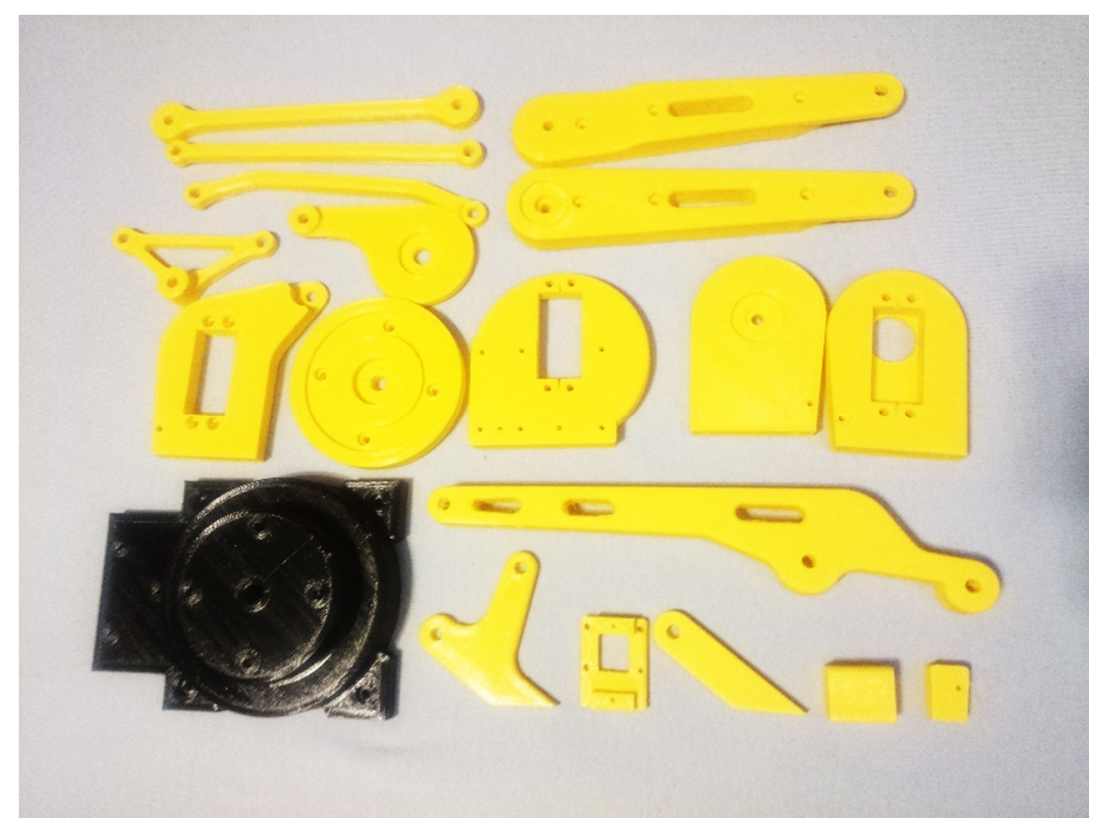

Rysunek 3. Widok wydrukowanych elementów zaprojektowanego robota [13]

Do napędzania ramion przewidziano serwomechanizmy modelarskie MG995, o wymiarach 40,6 × 19,8 × 37,8 mm i masie 55,2 g (Rysunek 4). Zasilając napięciem od 4,8 V do $6,0 \mathrm{~V}$ można uzyskać moment od $13 \mathrm{~kg} \cdot \mathrm{cm}(1,27 \mathrm{Nm})$ przy prędkości $0,17 \mathrm{~s} / 60^{\circ}$ do $15 \mathrm{~kg} \cdot \mathrm{cm}(1,47 \mathrm{Nm})$ przy prędkości $0,13 \mathrm{~s} / 60^{\circ}$. Zakres ruchu takiego napędu mieści się $\mathrm{w}$ przedziale od $0^{\circ}$ do $180^{\circ}$.

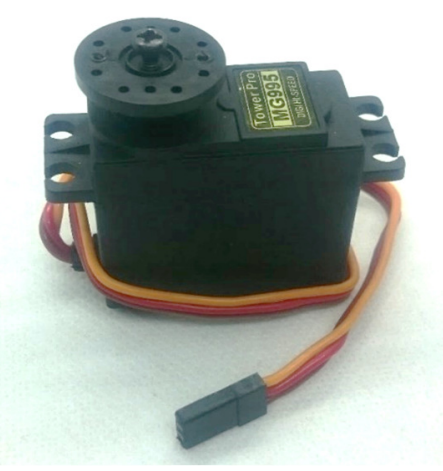

Rysunek 4. Zdjęcie serwomechanizmu MG995 z orczykiem [13]

Natomiast w podstawie członu 3 przewidziany jest widoczny na rysunku 5 serwomechanizm SG90, którego cechują niewielkie wymiary: $22 \times 11,5 \times 27 \mathrm{~mm}$ i masa $9 \mathrm{~g}$. Jego moment dla napięcia $4,8 \mathrm{~V}$ wynosi $1,8 \mathrm{~kg} \cdot \mathrm{cm}(0,18 \mathrm{Nm})$, a prędkość $0,1 \mathrm{~s} / 60^{\circ}$. Zakres ruchu jest taki sam jak dla MG995, czyli od $0^{\circ}$ do $180^{\circ}$. 


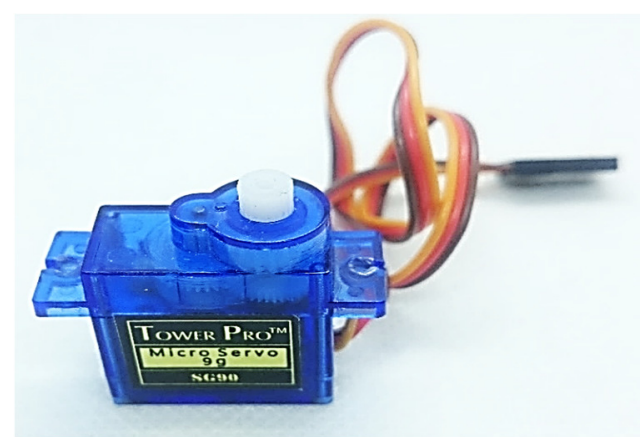

Rysunek 5. Zdjęcie serwomechanizmu SG90 [13]

Połączenie bezprzewodowe $\mathrm{Wi}$-Fi pomiędzy smartfonem, a robotem zrealizowano na dwa sposoby: przy pomocy płytki ESP-32 oraz łącząc moduł ESP8266EX z mikrokontrolerem Arduino Nano.

Płytka ESP-32 posiada wbudowany moduł ESP-WROOM-32. Układ ten pozwala na komunikację bezprzewodową w paśmie $2,4 \mathrm{GHz}$ zarówno poprzez $\mathrm{Wi}-\mathrm{Fi} 802.11 \mathrm{~b} / \mathrm{g} / \mathrm{n}$ jak i Bluetooth BLE (Bluetooth Low Energy) w wersji 4.2. Płytka wyposażona jest w konwerter USB-UART CP2102, dzięki któremu możliwa jest komunikacja oraz programowanie modułu przez złącze microUSB. Do uruchomienia wymagane jest napięcie o wartości $5 \mathrm{~V}$. Posiada mikrokontroler Dual Core Tensilica LX6 240 MHz i operuje pamięcią SRAM 520 KB oraz Flash 4 MB. Dysponuje 30 wyprowadzeniami GPIO, a jego wymiary to $52 \times 28 \times 8 \mathrm{~mm}$ [12].

Moduł WIFI ESP-01 (ESP8266EX) jest modułem zapewniającym łączność bezprzewodową wyłącznie technologią Wi-Fi w standardzie $802.11 \mathrm{~b} / \mathrm{g} / \mathrm{n}$. Moduł jest zasilany napięciem 3,3 V [11]. Z uwagi na małą liczbę wyjść/wejść GPIO, niezbędne jest zwiększenie wyprowadzeń np. przez podłączenie do osobnego mikrokontrolera takiego jak Arduino Nano. W celu połączenia z komputerem i zaprogramowania wymagane jest zastosowanie specjalnego konwertera USB-UART lub płytki Arduino. Do wgrywania programu zastosowano konwerter USB-UART (Rysunek 6), który zmodyfikowano poprzez doprowadzenie napięcia 3,3 V z VCC do CH_PD oraz dołączenie przycisku pomiędzy wyprowadzeniem GPIO_0 oraz GND. Wciśnięty przycisk podczas podłączania konwertera z wpiętym ESP-01, przełączy ten moduł $\mathrm{w}$ tryb programowania i umożliwi wgranie programu bezpośrednio z komputera.

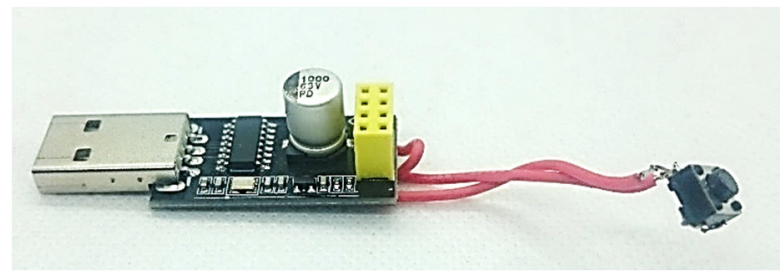

Rysunek 6. Zdjęcie konwertera USB - UART [13]

Połączenie Bluetooth zrealizowano na dwa sposoby, poprzez wyżej wspomnianą płytkę ESP-32 oraz moduł HC-05 połączony z mikrokontrolerem Arduino. 
Moduł HC-05 jest to układ umożliwiający komunikację z urządzeniami poprzez łączność Bluetooth w tym przypadku w wersji 2.0. Można go zasilić napięciem 3,6 do $6 \mathrm{~V}$. Moduł nie posiada żadnych wyjść GPIO dlatego niezbędne jest połączenie z mikrokontrolerem. Wymiana danych z Arduino możliwa jest poprzez sprzętową lub programową komunikację UART.

Arduino Nano (Rysunek 7) - jest to klon Arduino posiadający mikrokontroler ATmega328P. Można go zasilić przez złącze miniUSB lub podając na wejście do tego przeznaczone napięcie o wartości od 7 do $12 \mathrm{~V}$. Wykorzystana w projekcie płytka posiada $1 \mathrm{kB}$ pamięci SRAM i $1 \mathrm{kB}$ pamięci EEPROM oraz $32 \mathrm{kB}$ pamięci Flash służącej do przechowywania programów. Posiada 14 cyfrowych portów I/O (wejścia/wyjścia), w tym 6 wyjść PWM (modulacja szerokości impulsu), a także 8 wejść analogowych. Dzięki zastosowaniu konwertera CH340 możliwe jest programowanie z poziomu komputera przez port USB.

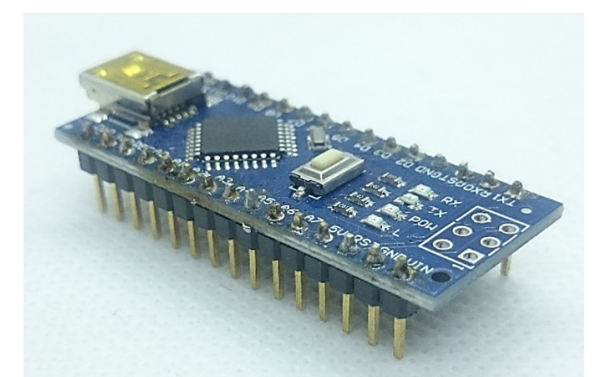

Rysunek 7. Zdjęcie ptytki Arduino Nano (klon) [13]

Do zasilenia układów zastosowano cztery ogniwa Li-Ion 18650 o napięciu znamionowym 3,6 V, połączonych szeregowo po dwa akumulatory, co daje napięcie na poziomie 7,2 V. Napięcie to następnie przechodzi przez przetwornicę XL4015 i zasila serwomechanizmy napięciem $5 \mathrm{~V}$. Zaletą tej przetwornicy jest regulowane napięcie wyjściowe za pomocą potencjometru na płytce, dzięki czemu w razie potrzeby można sterować mocą serwomechanizmów. Kolejną przetwornicę MP2307 zastosowano do zasilenia ESP-32 lub Arduino wartością napięcia równą $5 \mathrm{~V}$.

Elementy elektroniczne układu z płytką ESP-32 połączono według schematu na rysunku 8. Obowiązuje on dla pracy w obu trybach: Wi-Fi oraz Bluetooth. 


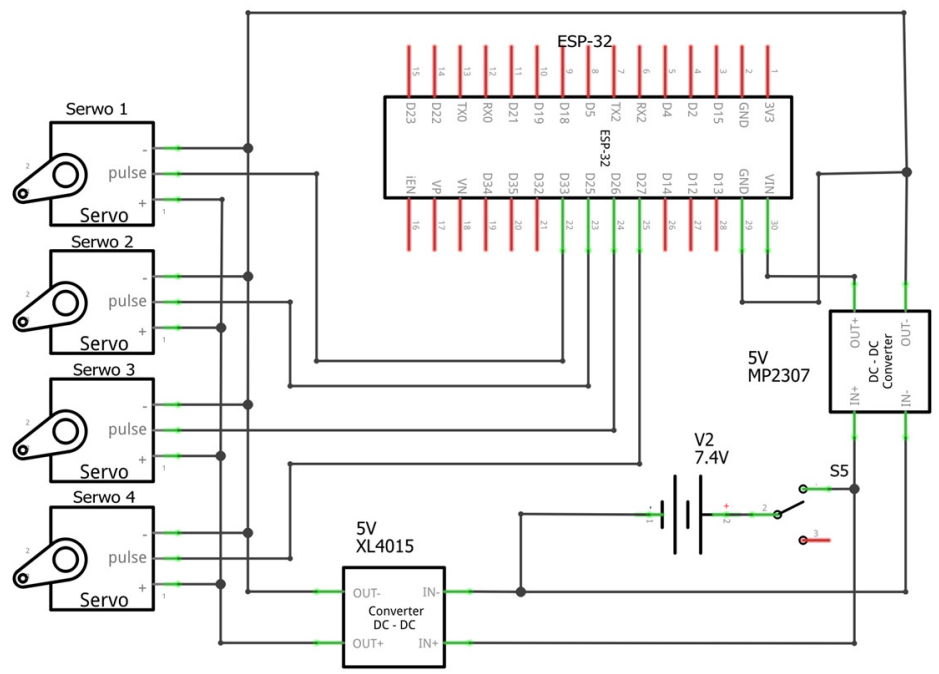

Rysunek 8. Schemat elektroniczny układu z ESP-32 wykonany w programie Fritzing [13]

Kolejny schemat (Rysunek 9) przedstawia połączenie mikrokontrolera Arduino Nano z modułem Wi-Fi ESP-01. Tutaj zasilanie $5 \mathrm{~V}$ podprowadzono do pinu 5V na płytce mikrokontrolera. Moduł Wi-Fi natomiast pracuje $\mathrm{z}$ napięciem 3,3 V, dlatego zastosowano stabilizator napięcia $5 \mathrm{~V}$ na $3,3 \mathrm{~V}$, ponieważ natężenie prądu pochodzące z wyjścia $3 \mathrm{~V} 3$ jest zbyt niskie do prawidłowego działania tego modułu.

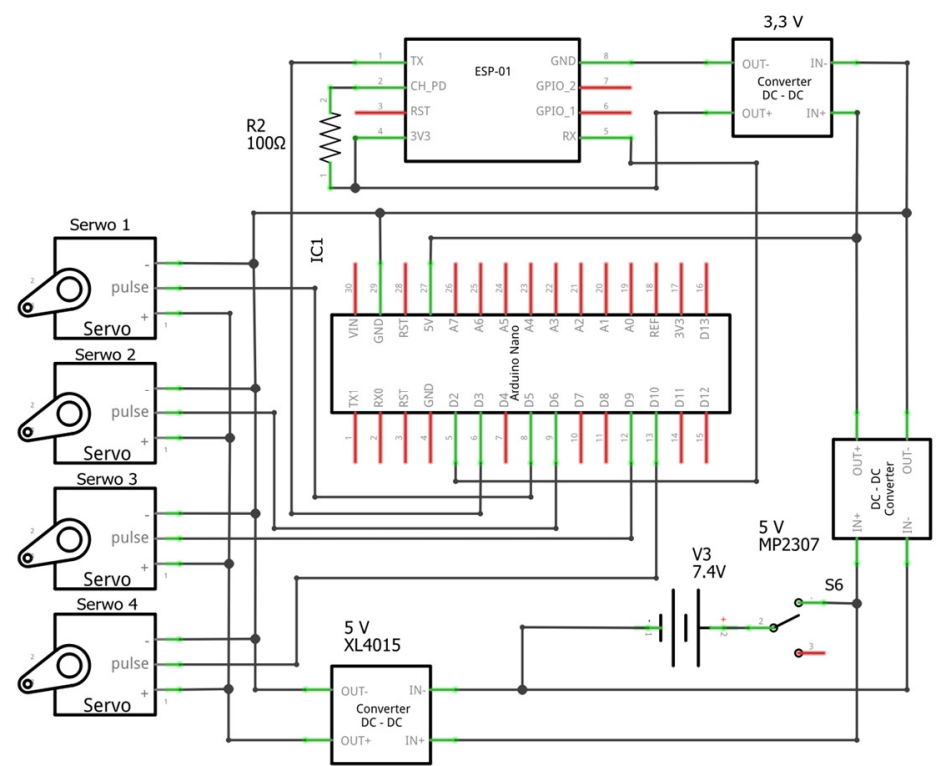

Rysunek 9. Schemat elektroniczny uktadu z Arduino Nano i ESP-01 wykonany w programie Fritzing [13] 
Piny komunikacyjne (RX, TX) modułu ESP-01 połączono do wyprowadzeń D03 i D02, które po zastosowaniu biblioteki SoftwareSerial.h w programie wgranym do Arduino Nano, pełnią rolę kanałów transmisji danych odpowiednio TX i RX. Wyjście CH_PD połączono poprzez rezystor $100 \Omega$ do wejścia $3 \mathrm{~V} 3$.

Układ do wymiany danych przez Bluetooth przedstawiono na schemacie na rysunku 10. Wejście VCC moduł HC-05 zasilono napięciem 5V z przetwornicę MP2307, masę podłączono do GND natomiast wyjścia transmisji, połączono na krzyż: TX do pinu D09 (programowy RX) w mikrokontrolerze, a RX do D08 (programowy TX).

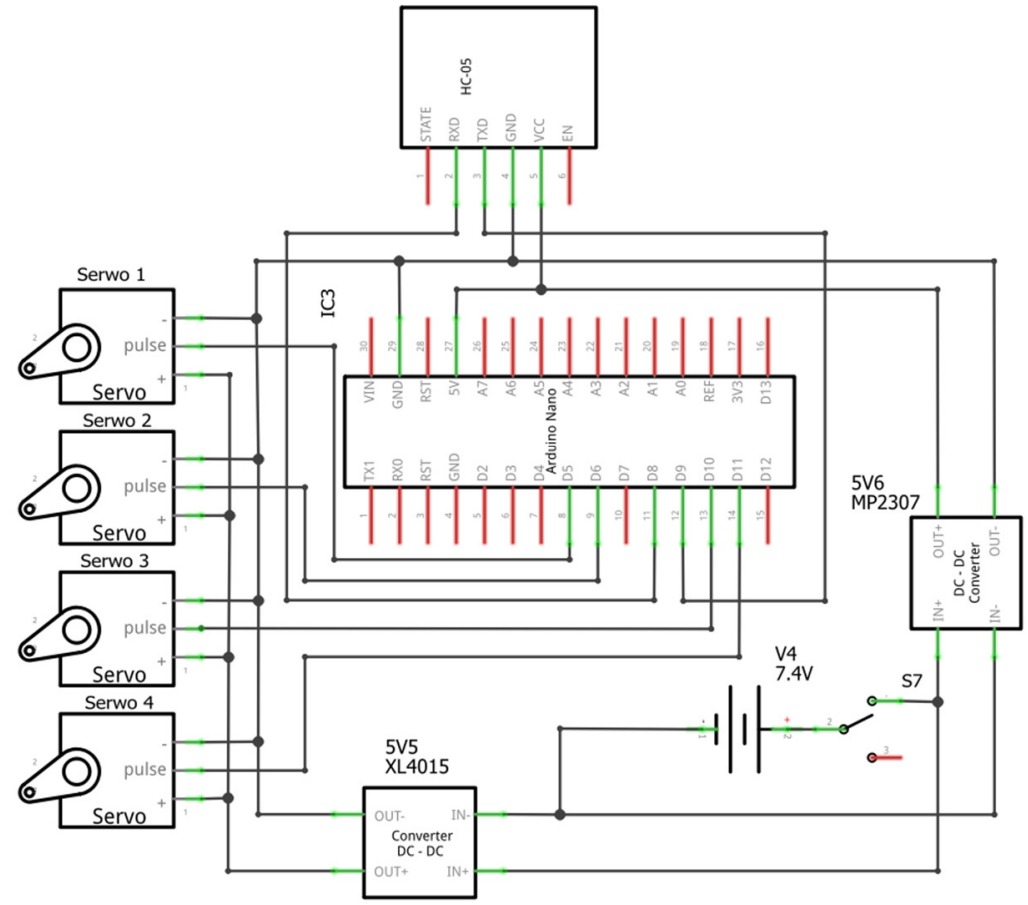

Rysunek 10. Schemat elektroniczny układu z Arduino Nano i HC-05 wykonany w programie Fritzing [13]

Wszystkie trzy schematy połączono na jednej płytce uniwersalnej. Dzięki zastosowaniu żeńskich listew goldpin raster 2,54 mm, moduły ESP-01 i HC-01 oraz płytki Arduino Nano i ESP-32 będzie można wyjmować i podmieniać w zależności od sposobu komunikacji. Na rysunku 11 przedstawiono gotowy układ elektroniczny. 


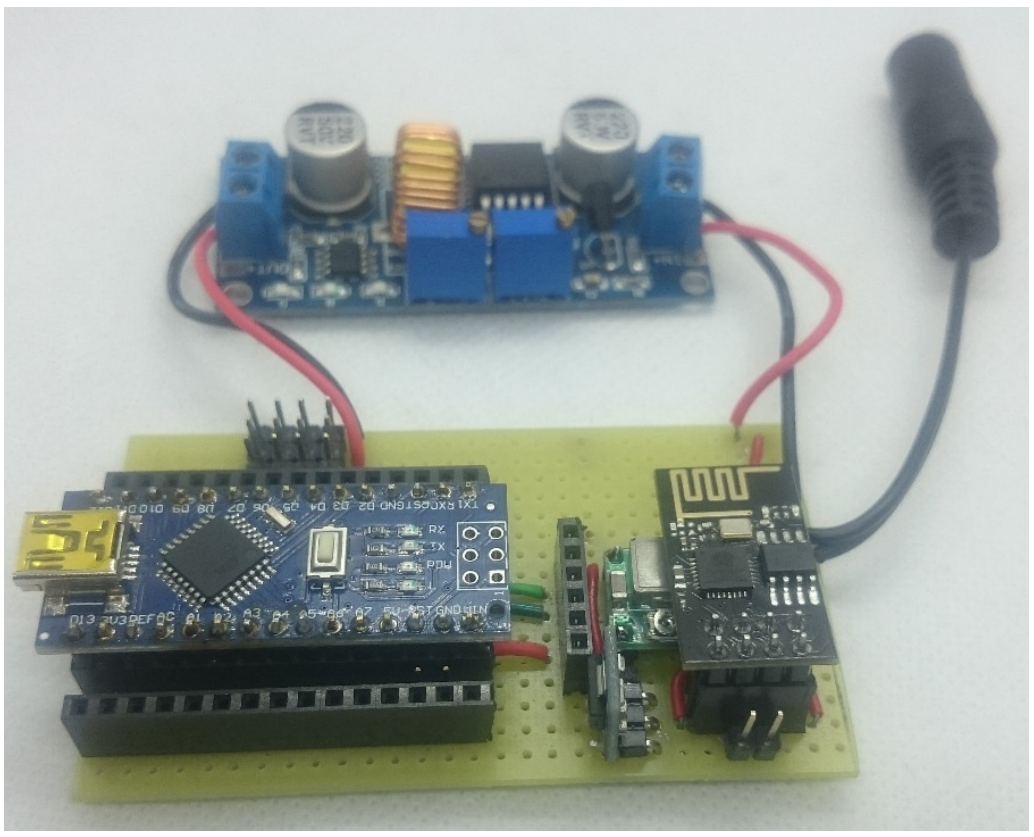

Rysunek 11. Zdjęcie zmontowanego układu elektronicznego [13]

Wykonaną płytkę zamocowano z tyłu podstawy robota oraz zasilono czterema ogniwami umieszczonymi w koszyku (Rysunek 12).

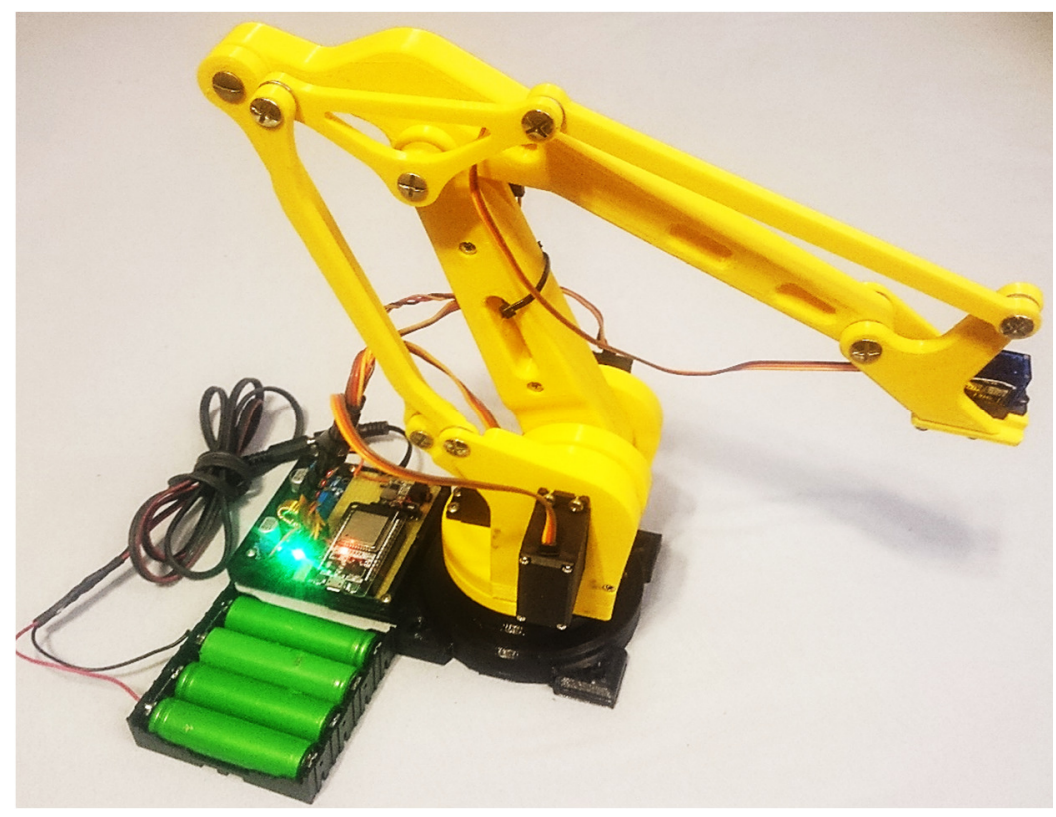

Rysunek 12. Zdjęcie wykonanego modelu robota [13] 


\section{Programowanie modułów}

Opracowano kody programów do urządzeń komunikacyjnych umożliwiających bezprzewodowe połączenie przez Wi-Fi oraz Bluetooth.

Każdy z wykonanych programów składa się z trzech głównych elementów: deklaracja zmiennych i bibliotek, funkcja void setup() oraz funkcja void loop(), w której zostały zawarte instrukcje odpowiadające za wymianę informacji oraz sterujące serwomechanizmami.

Moduł ESP-32 ma możliwość komunikacji bezprzewodowej przez obie badane metody, lecz programy zastały wgrane do mikrokontrolera osobno dla każdego połączenia.

Program obsługi Bluetooth dla płytki ESP-32 zawiera deklaracje bibliotek Servo.h, która zawiera funkcje ułatwiające obsługę serwomechanizmów, oraz BluetoothSerial.h, dzięki której możliwa jest transmisja danych.

Do płytki ESP-32 Wi-Fi wgrano także oddzielny program do komunikacji poprzez Wi-Fi. Wykorzystuje on protokół TCP/IP do komunikacji z serwerem.

W pierwszej kolejności zostały dołączone biblioteki WiFi.h oraz Servo.h. Ta pierwsza zawiera zbiór funkcji umożliwiających podłączenie się do sieci. Dalej znajdują się zmienne zawierające nazwę i hasło do sieci Wi-Fi, do której ma się podłączyć moduł oraz numer portu serwera. Dla ułatwienia zastosowano w programie kod umożliwiający przypisanie stałego adresu IP razem z bramą domyślną i maską podsieci. Wybrano taki numer adresu IP, aby nie był zajęty przez inne urządzenie podłączone do tej samej sieci.

Program dla modułu Bluetooth HC-05 jest bardzo podobny do wersji dla ESP32. Posiada bibliotekę SoftwareSerial.h, która umożliwia komunikację szeregową między modułem, a zadeklarowanymi wyprowadzeniami płytki Arduino Nano. Dzięki temu można pominąć piny TX oraz RX, które służą do komunikacji z komputerem, przez co używanie ich $\mathrm{z}$ innym urządzeniem może wprowadzić zakłócenia w działaniu, lub wywołać błędy podczas wgrywania kodu na płytkę.

\section{Projektowanie aplikacji sterującej}

Aplikację na smartfon z systemem Android wykonano przy pomocy kreatora aplikacji MIT App Inventor 2 dostępnej online [14] .

Aplikacja sterująca robotem składa się z pięciu ekranów:

1 Ekran wyboru okien „Opcje”,

2 Ekran do sterowania osiami robota „Sterowanie”,

3 Ekran do testowania połączenia Wi-Fi „Test Wi-Fi”,

4 Ekran do testowania połączenia Bluetooth „Test Bluetooth”,

5 Ekran z informacjami „Info”.

Ekran „Opcje” (rysunek 13a) zawiera jedynie przyciski, umożliwiające przejście do czterech pozostałych ekranów, a także zamknięcie aplikacji.

Okno „Sterowanie” (rysunek 13b) daje możliwość poruszania robotem przy pomocy suwaków lub przycisków, po uprzednim skomunikowaniu się przez wybrany protokół transmisji. W celu połączenia przez Wi-Fi należy kliknąć przycisk „Połącz przez Wi-Fi”, a następnie po pojawieniu się pola tekstowego wpisać adres IP modułu sieci bezprzewodowej. Pole to można następnie ukryć. Po poprawnym połączeniu możliwe 
będzie sterowanie członami robota. Jeżeli natomiast adres IP będzie niepoprawny wyświetli się komunikat „Niepoprawny adres IP”. Komunikacja przez Bluetooth wykonywana jest po kliknięciu przycisku „Połącz przez Bluetooth” i wybraniu z listy dostępnych urządzeń modułu HC-05 lub ESP-32_Bluetooth w zależności, które urządzenie jest aktualnie uruchomione.

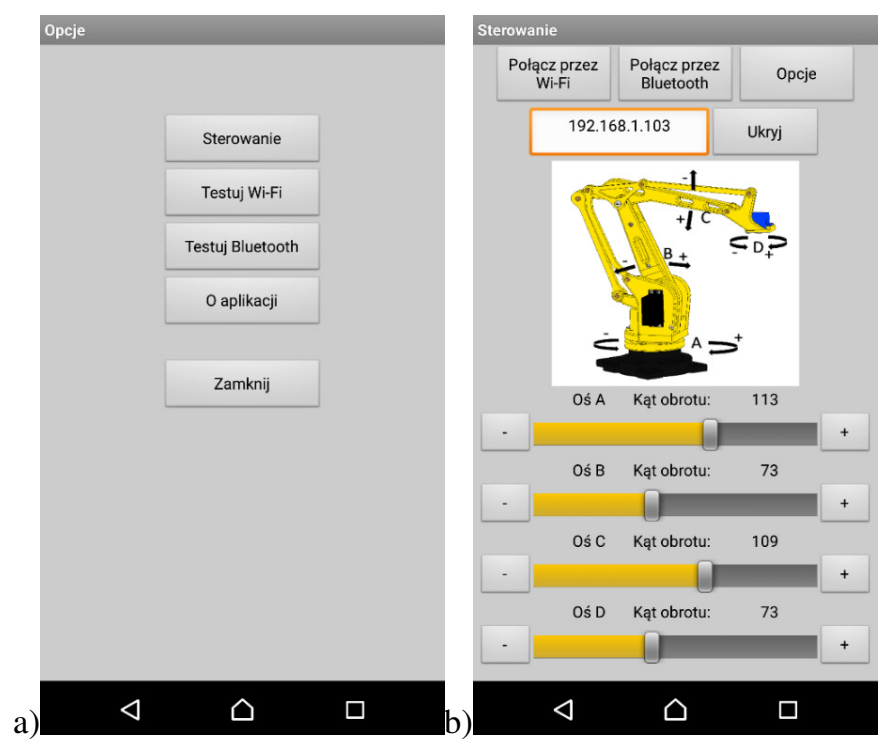

Rysunek 13. Widok ekranu aplikacji do sterowania modelem robota: a) na otwartym oknie"Opcje" , b) aplikacja ustawiona na zakładke ,Sterowanie”[13]

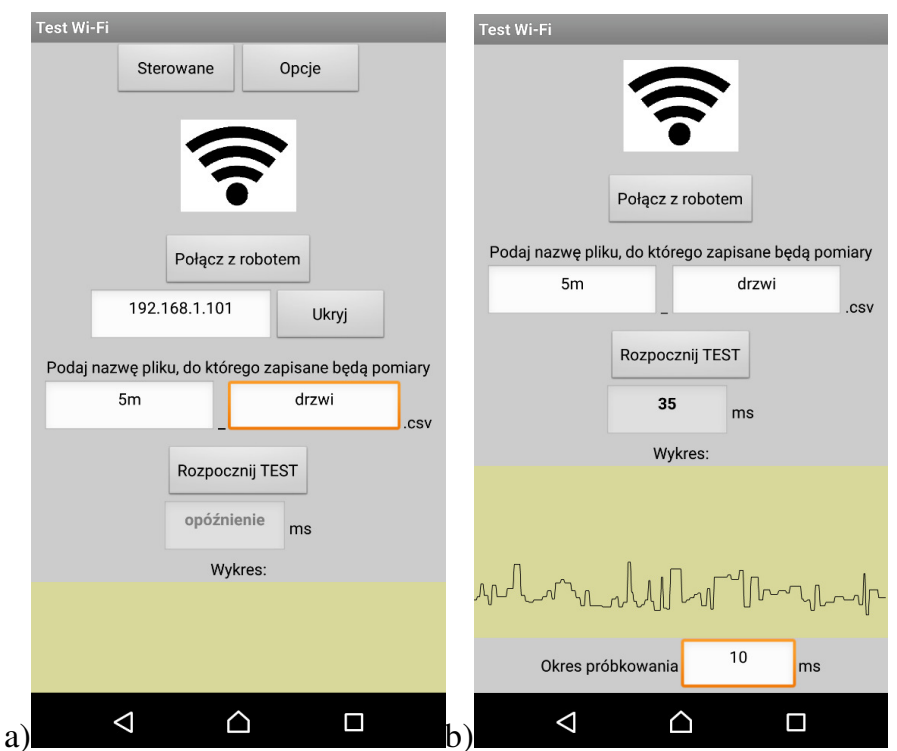

Rysunek 14. Widok ekranu aplikacji do sterowania modelem robota: a) z aplikacja ustawiona na ekran testu Wi-Fi, b) przedstawiający wykres z opóźnieniami[13] 
Ekran „Test Wi-Fi” widoczny na rysunku 14a umożliwia przeprowadzenie testu połączenia bezprzewodowego, który polega na obliczeniu czasu opóźnienia sygnału dla stu prób oraz wyeksportowaniu danych do pliku z rozszerzeniem .csv o nazwie podanej przez użytkownika. Test rozpoczyna się po wciśnięciu przycisku „Rozpocznij TEST” po uprzednim wprowadzeniu poprawnego adresu IP urządzenia Wi-Fi połączonego z robotem, w polu widocznym po kliknięciu przycisku „Połącz z robotem". Aktualne wartości opóźnienia pojawiają się w polu z napisem „opóźnienie”. Poniżej wstawiono pole, na którym generuje się wykres na podstawie otrzymanych wyników opóźnienia (rysunek 14b). Na samym dole można zmienić okres czasu próbkowania. Jeżeli wpisany adres IP będzie nieprawidłowy pojawi się komunikat o tym informujący.

Ekran „Test Bluetooth” działa na tej samej zasadzie jak ekran komunikacji Wi-Fi. Różnica polega na tym, że połączenie zostaje nawiązane poprzez Bluetooth po wybraniu z listy urządzeń widocznej po kliknięciu przycisku „Połącz” (rysunek 15).

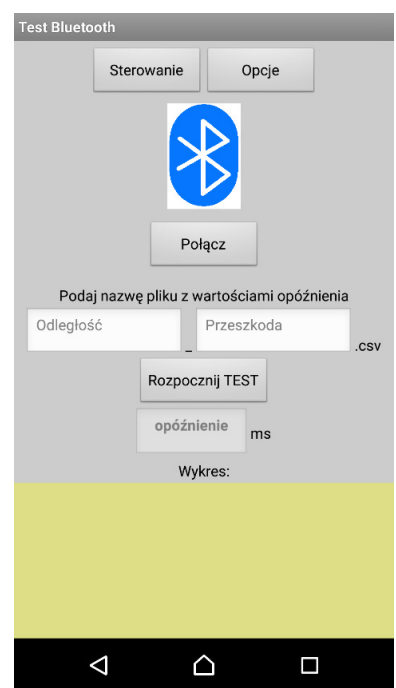

Rysunek 15. Zrzut ekranu aplikacji sterujacej z uruchomionym oknem "Test Bluetooth" [13]

\section{Wyniki badań i analizy testów komunikacji bezprzewodowej}

Test prędkości sygnału wykonano dla każdego $\mathrm{z}$ trzech modułów. Badania przeprowadzono $\mathrm{w}$ budynku mieszkalnym dla trzech odległości oraz $\mathrm{z}$ dwiema przeszkodami postawionymi na drodze transmisji. Wykonaną aplikację uruchomiono na smartfonie Lenovo K6 z systemem Android w wersji 6.0.1., który wyposażony jest $\mathrm{w}$ moduł Bluetooth w wersji v4.2 oraz moduł Wi-Fi ze standardem v802.11 b/g/n pracującymi z częstotliwością 2,4 GHz.

\subsection{Komunikacja bezprzewodowa Wi-Fi}

Testy przeprowadzono po podłączeniu się do lokalnej sieci rozgłaszanej przez router Wi-Fi TP-LINK Archer C6 posiadający standard $802.11 \mathrm{a} / \mathrm{c}$ i pracujący w trybie Access Point z częstotliwością 2,4 GHz. 
W pierwszej kolejności połączono się z siecią Wi-Fi (rysunek 16) przy pomocy ESP$32 \mathrm{z}$ wgranym odpowiednim programem. Następnie w aplikacji na smartfonie otworzono okno Test Wi-Fi i wpisano adres IP urządzenia, które ustalono w programie. Po uzupełnieniu pozycji zawierających nazwę pliku, do którego zapisują się pomiary, uruchomiono test przyciskiem „Rozpocznij TEST”.

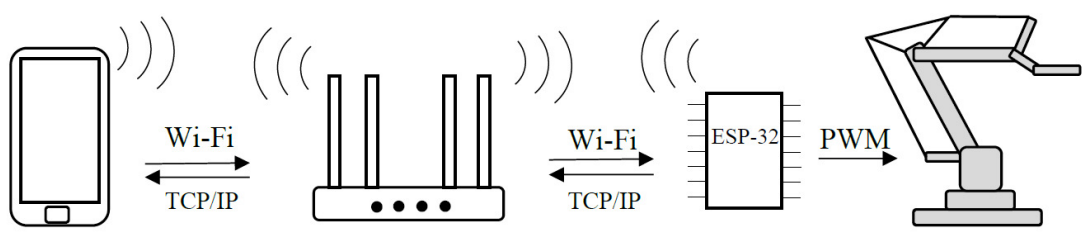

Rysunek 16. Schemat nawiązywania komunikacji bezprzewodowej Wi-Fi z modutem ESP-32 [13]

Wyniki przeprowadzonych testów dla różnych odległości przedstawiono na rys.17.

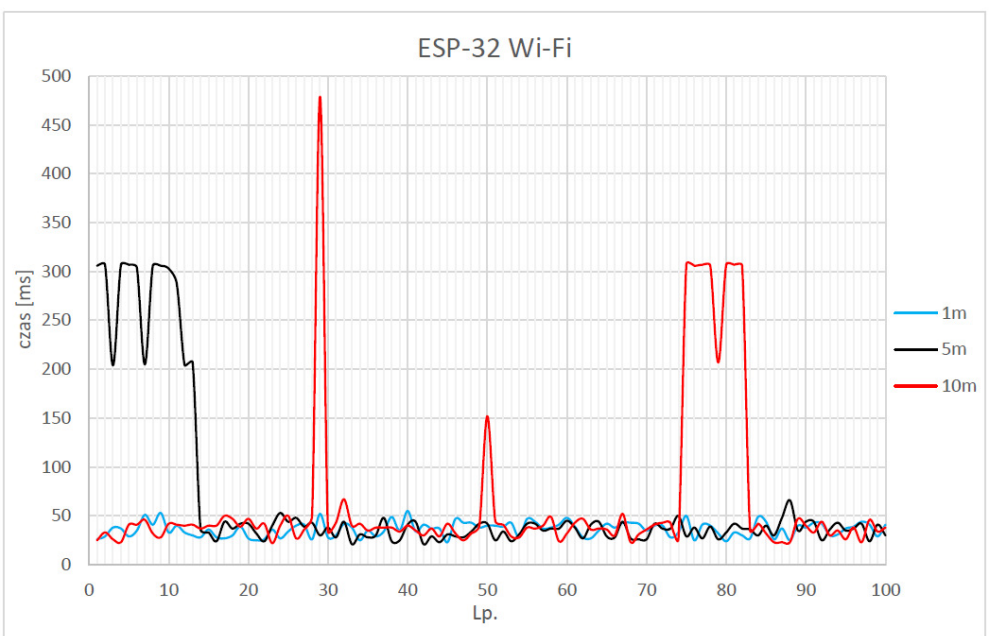

Rysunek 17. Wykres opóźnień modułu Wi-Fi ESP-32 dla różnych odległości [13]

Na wykresie przedstawionym na rysunku 17, dla odległości 5 m można zauważyć wyższe wartości opóźnienia w początkowej fazie testu. Spowodowane jest to przejściem modułu w stan niższego poboru mocy. Dla odległości $1 \mathrm{~m}$ oraz $5 \mathrm{~m}$, nie ma widocznych różnic w opóźnieniu, co świadczy o dobrej jakości połączenia. Po oddaleniu się o $10 \mathrm{~m}$ od routera, wystąpiły niewielkie zwłoki czasowe w odczytach danych. Opóźnienia oscylują w granicach 30 - 50 ms.

Do przeprowadzenia badania komunikacji za pomocą modułu ESP-01 wymagane jest zastąpienie płytki ESP-32 płytką Arduino Nano z wgranym odpowiednim programem, oraz wpięcia modułu ESP-01 w odpowiednie miejsce układu elektronicznego robota (rysunek 18). Rysunek 19 przedstawia wykres opóźnień modułu ESP-01 dla wybranych odległości. 


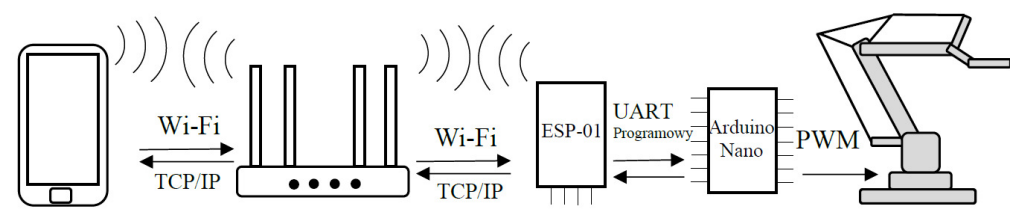

Rysunek 18. Schemat nawiąywania komunikacji bezprzewodowej Wi-Fi z modutem ESP-01 [13]

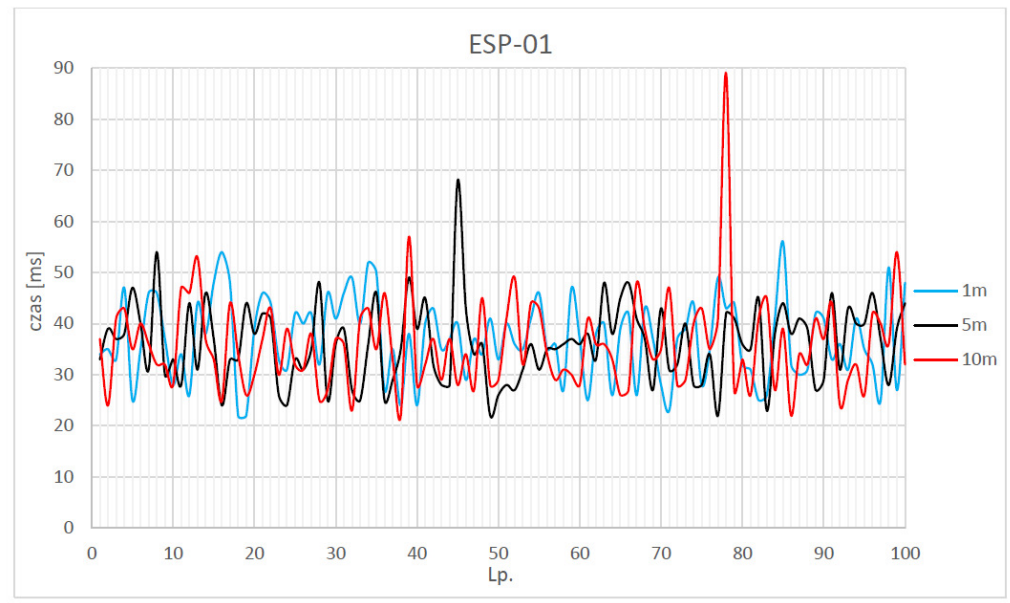

Rysunek 19. Wykres opóźnień modułu ESP-01 dla różnych odległości [13]

Badane opóźnienia dla modułu ESP-01 charakteryzują się niskimi wartościami pingu dla każdej z odległości, które znajdują się w podobnym przedziale jak w przypadku modułu ESP-32. Największe opóźnienie zarejestrowano dla odległości $10 \mathrm{~m}$.

\subsection{Komunikacja bezprzewodowa Bluetooth}

Test komunikacji poprzez Bluetooth, podobnie jak przez Wi-Fi przeprowadzono dla obu konfiguracji: z modułem ESP-32 oraz z modułem HC-05 i Arduino. (rysunek 20 i 22). Wyniki badań zamieszczono na rysunkach 21 i 23.

Badanie czasu odpowiedzi połączeniem Bluetooth przeprowadzono na płytce ESP32, do której wgrano program umożliwiający transmisję. W aplikacji na smartfonie, otworzono okno „Test Bluetooth”, a następnie połączono się z badanym urządzeniem poprzez wciśnięcie przycisku „Połącz” i wybraniu odpowiedniej pozycji z listy. Po poprawnym połączeniu, wpisaniu nazwy pliku i wciśnięciu Przycisku „Rozpocznij TEST" rozpoczęto badanie.

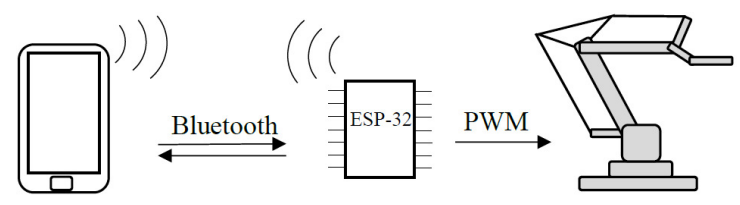

Rysunek 20. Schemat nawiazywania komunikacji bezprzewodowej Bluetooth z modutem ESP-32 [13] 


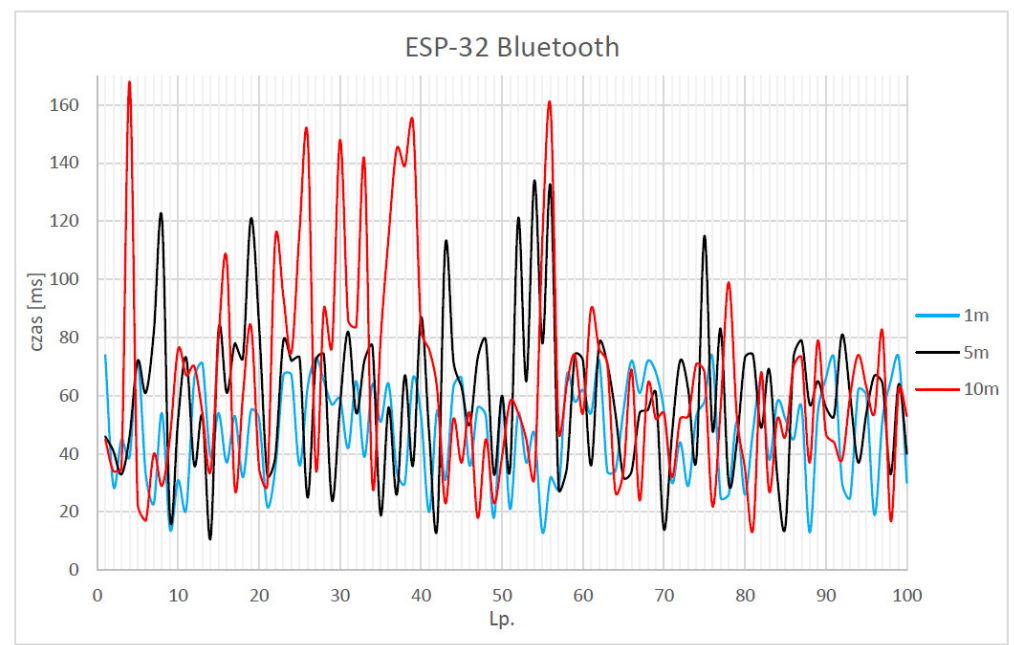

Rysunek 21. Wykres opóźnień modułu Bluetooth ESP-32 dla różnych odległości [13]

W przypadku połączenia Bluetooth opóźnienia posiadają większe wartości i oscylują w granicach $20-80 \mathrm{~ms}$. W odległości $1 \mathrm{~m}$ ping nie wykazuje większych pików i utrzymuje transmisję na podobnym poziomie. Po oddaleniu się na $5 \mathrm{~m}$ można zauważyć skoki o wartości około $120 \mathrm{~ms}$, natomiast na dystansie $10 \mathrm{~m}$ sięgają już $150 \mathrm{~ms}$.
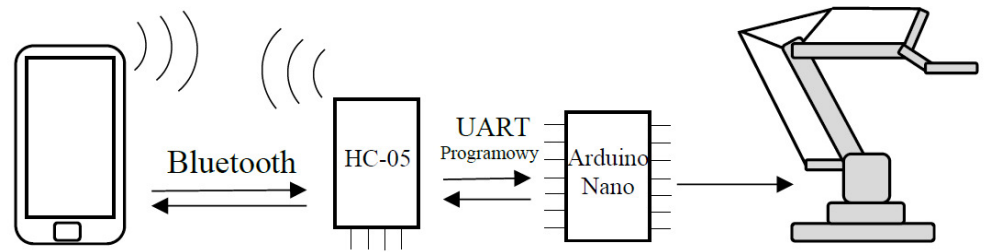

Rysunek 22. Schemat nawiazywania komunikacji bezprzewodowej Bluetooth z modutem HC-05 [13]

Wykres na rysunku 23 charakteryzuje się dość niskimi wartościami opóźnienia oraz stabilną pracą dla każdej z badanych odległości. W czasie badania zanotowano także kilka wartości na poziomie 4-5 ms, które są niemal niemożliwe do uzyskania przez moduł Bluetooth. 


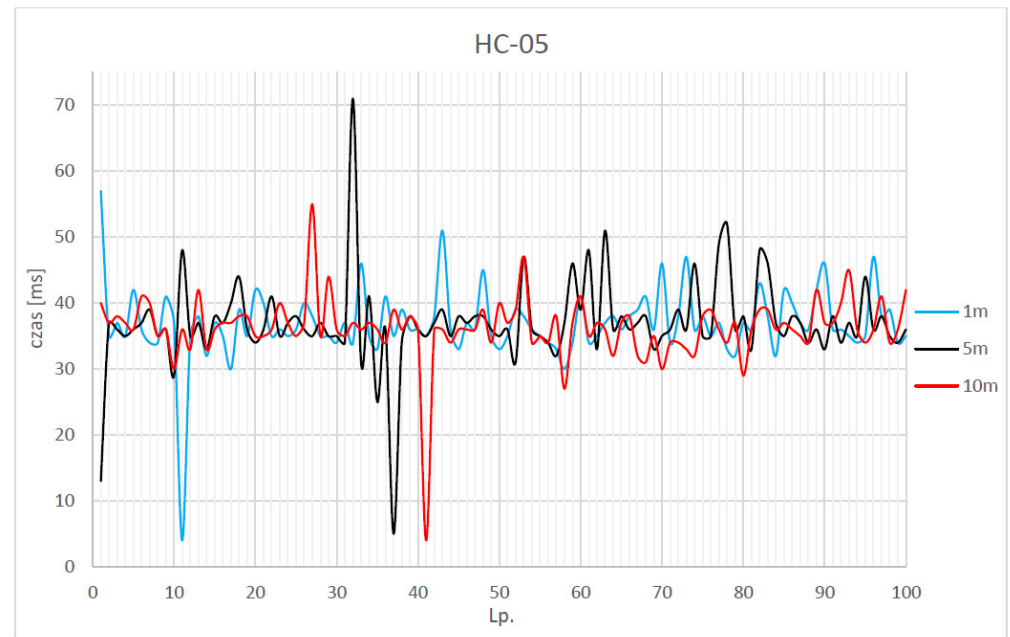

Rysunek 23. Wykres opóźnień modutu Bluetooth HC-05 dla różnych odległości [13]

Powodem takich wyników są błędy w wysyłaniu wartości z pingiem, do aplikacji na smartfonie dociera tylko pierwsza cyfra opóźnienia.

\subsection{Badanie opóźnień ze źródłami zakłóceń}

Wszystkie moduły przebadano pod względem radzenia sobie z zakłóceniami ustawionymi na drodze transmisji sygnału. Jako źródła blokujące transmisje posłużyła konstrukcja z blachy oraz kuchenka mikrofalowa postawiona na drodze transmisji.

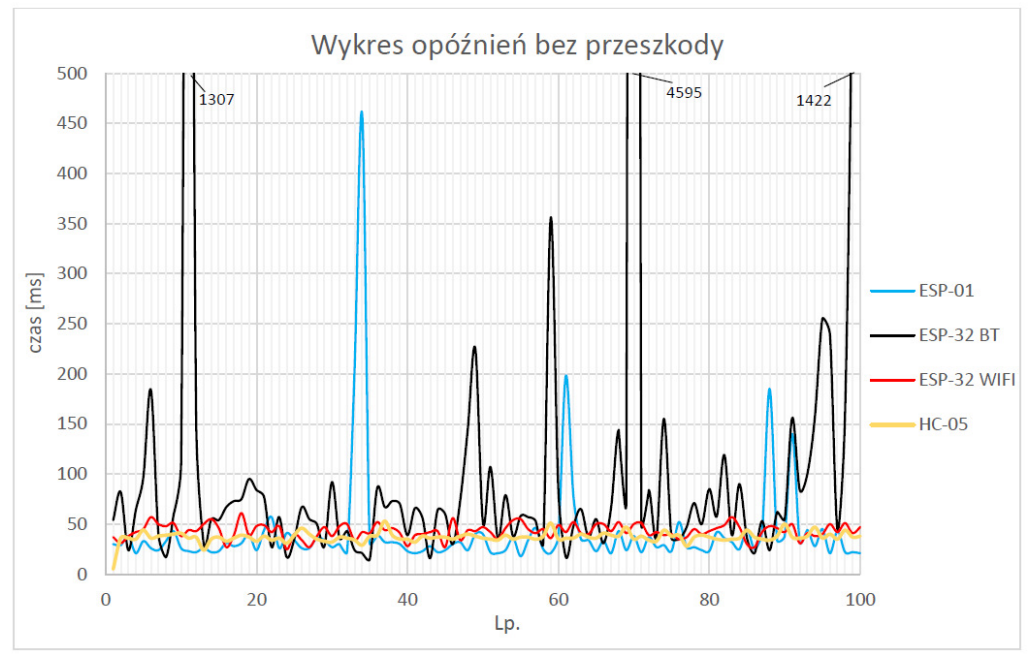

Rysunek 24. Wykres opóźnień dla modułów odgrodzonych blachą [13]

Pierwszym źródłem ograniczenia zasięgu była prostopadłościenna konstrukcja z odgórnym dostępem, wykonana z blachy stalowej o grubości 1,5 mm., do której włożono robota wyposażonego w moduł komunikacyjny. Podczas badania jakości 
Wi-Fi, router oddalono o $5 \mathrm{~m}$ od badanego obiektu, natomiast urządzenie mobilne znajdowało się przy badanych modułach poza przeszkodą. Rezultaty uzyskane z pomiarów przedstawiono graficznie na rysunku 24.

Na przedstawionym na rysunku 24 wykresach można zauważyć, że największe problemy z komunikacją sprawia połączenie Bluetooth na urządzeniu ESP-32. Opóźnienie dochodzi nawet do ponad 4,5 sekundy. Najlepiej poradziły sobie moduły HC-05 oraz ESP-32 z połączeniem Wi-Fi.

Kolejną przeszkodą, którą posłużono się do przetestowania wpływu na opóźnienie transmisji sygnału była kuchenka mikrofalowa Panasonic NN-SD446W. Urządzenie to postawiono $\mathrm{w}$ połowie drogi między modułami, a oddalonym o $5 \mathrm{~m}$ routerem (Wi-Fi) lub smartfonem (Bluetooth). Zdecydowano się na takie źródło zakłóceń ze względu na częstotliwość z jakim pracuje - $2450 \mathrm{MHz}$, a więc znajduje się $\mathrm{w}$ paśmie częstotliwości pracy badanych modułów. Kuchenkę ustawiono na moc 900 W, po czym ją uruchomiono, a następnie przeprowadzono testy. Rezultaty przeprowadzonych testów zaprezentowano na rysunku 25.

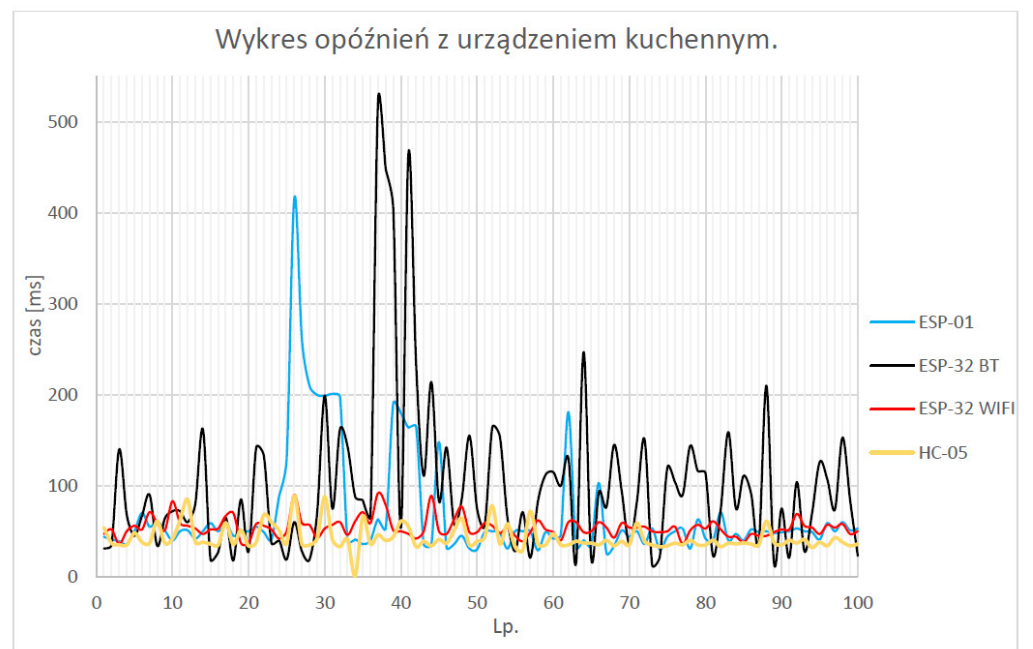

Rysunek 24. Wykres opóźnień dla modułów z włączoną kuchenka mikrofalową [13]

Podobnie jak w przypadku odgrodzenia blachą, najgorzej wypadły moduły ESP-01 oraz ESP-32 w wersji z Bluetooth. Wartości pingów dochodziły do około $200 \mathrm{~ms}$, a miejscami nawet do około $400 \mathrm{~ms}$ oraz $500 \mathrm{~ms}$. Pozostałe moduły poradziły sobie bez większych trudności.

Moduły komunikacyjne przetestowano również pod kątem zasięgu. Badanie przeprowadzono na zewnątrz budynku, w obszarze, w którym nie znajdowało się żadne źródło zakłóceń. W przypadku połączenia $\mathrm{Wi}$-Fi, router podłączony przewodem Ethernet postawiono przed prywatnym budynkiem, dlatego też maksymalny zasięg pomiaru był ograniczony do terenu posesji. Natomiast moduł Bluetooth ze względu na brak urządzeń pośredniczących w komunikacji nie jest ograniczony do określonego obszaru.

Uzyskane wyniki badania zasięgu przedstawiają się następująco dla określonych modułów komunikacyjnych: ESP-32 Wi-Fi - >35 m, ESP -01 - >30m, ESP-32 Bluetooth $-20 \mathrm{~m}, \mathrm{HC}-05-20 \mathrm{~m}$. 
Dla połączenia Wi-Fi odległość około 35 m routera od obu modułów i smartfona, z którego testowano łączność nie przyniosła większych zmian wopóźnieniu. Natomiast w przypadku płytki ESP-32 łączność Bluetooth zatraciła się w odległości około $20 \mathrm{~m}$. Moduł HC-05 wykazał się nieznacznie lepszym zasięgiem, ponieważ rozłączył się ze smartfonem po około $30 \mathrm{~m}$.

\section{Podsumowanie i wnioski}

Bezprzewodowy dostęp do informacji staje się coraz częściej niezbędną technologią wprowadzaną nie tylko dla celów prywatnych przez użytkowników domowych, ale także w przemyśle i usługach. Zdalne pozyskiwanie danych przez urządzenia mobilne i nie tylko, usprawnia funkcjonowanie procesów technologicznych poprzez m.in monitorowanie pracy maszyn czy możliwość zmiany parametrów z dowolnego miejsca. O ile przewodowe połączenie można uznać za bardziej niezawodne, to obecny postęp w dziedzinie Internetu bezprzewodowego czy Bluetooth zapewnia coraz większą stabilność łącza oraz możliwość łatwej rozbudowy sieci. Bezprzewodowe połączenie w niektórych przypadkach okazuje się jedynym rozwiązaniem. Przykładem jest wdrażanie systemów robotów autonomicznych, które stają się coraz powszechniejszym rozwiązaniem i wymagają jak najlepiej funkcjonującej komunikacji bezprzewodowej.

Badania przeprowadzone w niniejszej pracy ukierunkowane są na przeanalizowaniu ogólnodostępnych modułów bezprzewodowych integralnych ze środowiskiem Arduino. Na podstawie przeprowadzonych testów opóźnienia w zależności od odległości można stwierdzić, że moduły korzystające $\mathrm{z}$ połączenia WLAN charakteryzują się lepszymi wynikami. Potwierdza to także test zasięgu, który wskazuje na przewagę Wi-Fi nad połączeniem Bluetooth. Większy zasięg testowanych urządzeń Wi-Fi wynika z mocy ich nadajników, które posiadają prawie dwukrotnie wyższe wartości, lecz obarczone jest to większym zużyciem prądu. Zasięg można zwiększyć poprzez rozbudowę sieci o specjalne adaptery Bluetooth (od wersji 4.1), lub o kolejne routery w przypadku sygnału Wi-Fi.

Badanie wpływu zakłóceń uwidoczniło słabe strony płytki ESP-32 działającego w trybie Bluetooth, oraz płytki ESP-01. Odgrodzenie modułów przy pomocy blachy stalowej wpłynęło najbardziej na te dwa urządzenia komunikacyjne. Ze specyfikacji Bluetooth 2.0 wynika, że jest ono ponad dwukrotnie szybsze niż w przypadku wersji $4.2(2.0$ - do $2,1 \mathrm{Mb} / \mathrm{s}, 4.2$ - $800 \mathrm{~kb} / \mathrm{s})$, ale również wiąże się z tym pojawienie nieprawidłowości w transmisji, co w nowszej wersji jest wyeliminowane.

Mimo że kuchenka mikrofalowa pracuje z częstotliwością zbliżoną do pracy modułów, to jest ona na tyle zabezpieczona, aby fale elektromagnetyczne nie wychodziły poza obudowę. Mimo to pojawiły się wyższe wyniki w opóźnieniu, co mogło być spowodowane samą obecnością urządzenia o metalowej konstrukcji w pobliżu drogi transmisji.

Biorąc pod uwage proces programowania i użytkowania przetestowanych modułów, to zdecydowanie najlepszym wyborem jest ESP-32, ponieważ oprócz tego, że posiada obie metody łączności Wi-Fi oraz Bluetooth, to jeszcze sam w sobie jest mikrokontrolerem, posiadającym liczne wyjścia. W porównaniu do płytki ESP-01 połączonej z Arduino Nano, cechuje się większą stabilnością wymiany danych oraz prostotą programowania, a także nie wymaga wykonywania łączenia dodatkowych 
elementów. W odniesieniu do modułu HC-05, ESP-32 oprócz wspomnianych wcześniej argumentów posiada także nowszą wersję Bluetooth, co wiąże się z większymi możliwościami wykorzystania. Koszty każdej z konfiguracji (ESP-32, HC-05 + Arduino Nano, ESP-01 +Arduino Nano) przy założeniu, że w ofercie nie znajdują się oryginalne wersje, wychodzą na tym samym poziomie.

\section{LITERATURA}

1. MONK S.: Arduino dla początkujących. Podstawy i szkice. Helion, Gliwice 2019.

2. Materiały opracowane w ramach Programu "Mistrzowie Kodowania" finansowanego przez Samsung Electronics Polska:

https://www.math.uni.lodz.pl// zofiawal/AI_calosc.pdf, 12.03.2021.

3. KURTYNIK I. P., KARPIŃSKI M.: Bezprzewodowa transmisja informacji. F. P. PAK, Warszawa 2008.

4. BIEŃKOWSKI M.: Sieci bezprzewodowe w przemyśle: https://automatykaonline.pl/Artykuly/Komunikacja/Sieci-bezprzewodowe-wprzemysle2, 12.03.2021.

5. Serwis: https://botland.com.pl/blog/bluetooth-jak-to-dziala/, 05.03.2021.

6. GOSZCZYŃSKI T.: Komunikacja bezprzewodowa w zastosowaniach przemysłowych. Pomiary Automatyka Robotyka, 6(2013), 22-28.

7. Serwis: https://automatykab2b.pl/temat-miesiaca/41386-swiatlowody-wprzemysle-czesc-1-swiatlowodowe-sieci-komunikacyjne/strona/l-swiatlowodyw-przemysle-transporcie-i-energetyce, 11.03.2021.

8. ZDANOWICZ R.: Podstawy robotyki. Wydawnictwo Politechniki Śląskiej, Gliwice 2012.

9. ZIELIŃSKI B., TOKARZ K.: Transmisja bezprzewodowa w standardzie IrDA. Wydawnictwo Politechniki Śląskiej, "Zeszyty Naukowe Politechniki Śląskiej. Informatyka", 36(1999),661-676.

10. Serwis: https://new.abb.com/products/robotics/industrial-robots/irb-460, 11.03.2021.

11. Serwis: https://nurdspace.nl/images/ele0/ESP8266_Specifications_English.pdf, 12.03.2021.

12. Serwis: https://botland.com.pl/index.php?controller=attachment\&id_attachment=1810, dostęp 11.03.2021.

13. KOŁODZIEJCZYK P.: Projekt oraz wykonanie robota wraz ze sterowaniem bezprzewodowym. Prada dyplomowa magistrska. Akademia TechnicznoHumanistyczna w Bielsku-Białej, Bielsko-Biała 2021.

14. Serwis: http://ai2.appinventor.mit.edu, 08.03.2021. 